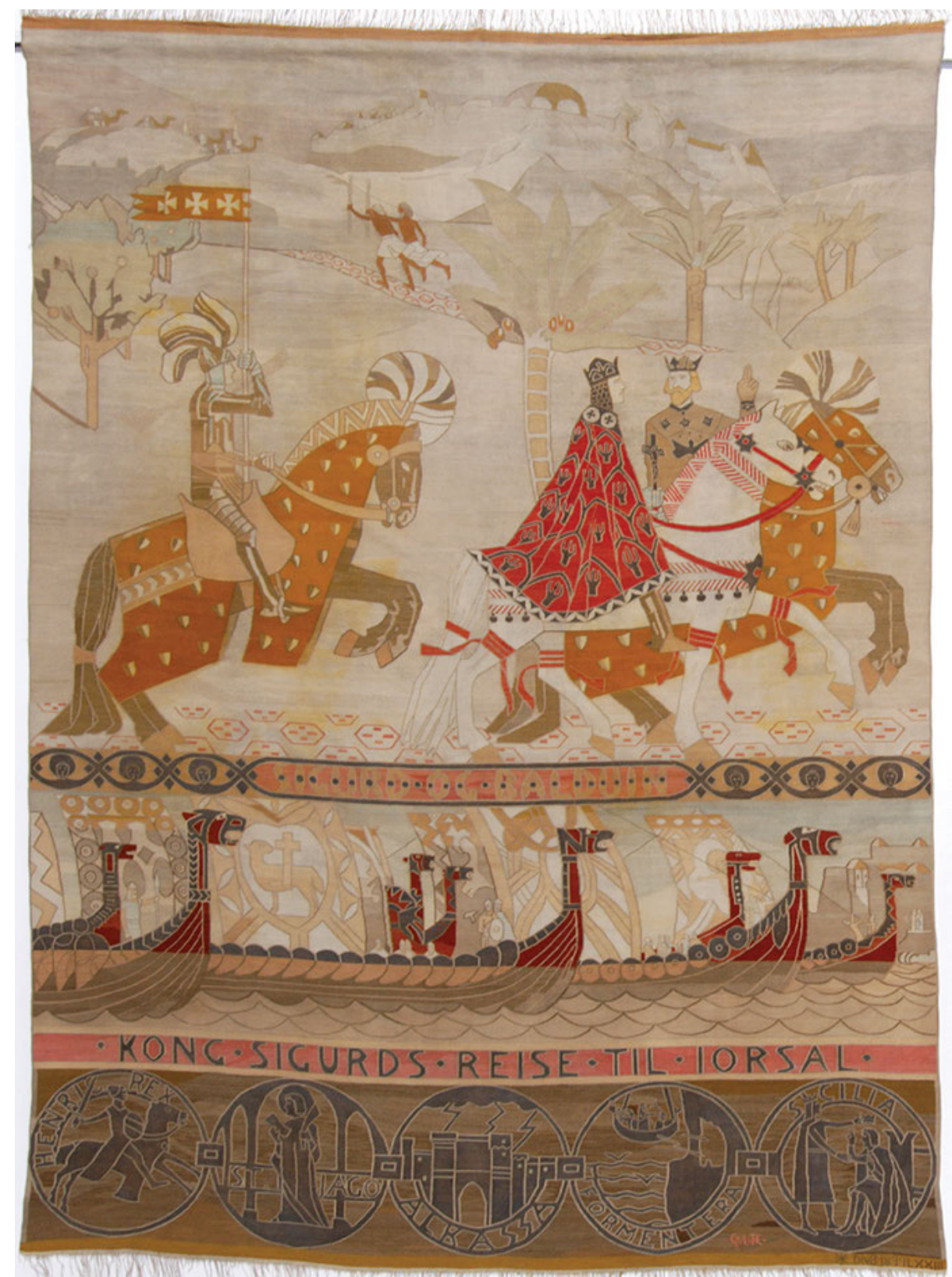

Fig. 28.1: Sigurd and Baldwin, 1900. Tapestry made by The Norwegian Tapestry Weaving Company/ Det norske Billedvæveri. $456 \times 340 \mathrm{~cm}$. The Royal Palace, Oslo. Photo: Kjartan Hauglid, De kongelige samlinger.

๑ Open Access. ( 2021 Torild Gjesvik, published by De Gruyter. (@) BY-NC-ND This work is licensed under the Creative Commons Attribution-NonCommercial-NoDerivatives 4.0 International License.

https://doi.org/10.1515/9783110639476-029 


\section{Chapter 28 \\ Weaving the Nation: Sigurd the Crusader and the Norwegian National Tapestries}

The Norwegian National Tapestries (1900) portray King Sigurd the Crusader (c.1090-1130) who travelled to Jerusalem in the early twelfth century. This chapter explores how these two tapestries came into being and asks how the Crusader king became a relevant symbol for the Norwegian nation around 1900. The iconography of the tapestries is analysed and compared to the narrative of King Sigurd as it is told in The Saga of the Sons of Magnús from the thirteenth century. The comparison reflects different versions of King Sigurd, as well as changing perceptions of Jerusalem.

In the art collection of the Royal Palace in Oslo there are two monumental tapestries representing the Norwegian king Sigurd Magnusson (c.1090-1130) in Jerusalem and Constantinople (Figs. 28.1 and 28.2). The tapestries were made in 1900, almost 800 years after the king's journey. King Sigurd travelled from Norway in 1108 and reached the Holy Land in the year 1111. The expedition earned him the byname Jorsalfare in Norwegian [Jerusalem-traveller], after the Old Norse name for Jerusalem: Jorsal. ${ }^{1}$ In English he is often called Sigurd the Crusader, pointing to the purpose of the journey. King Sigurd's crusade took place after the first wave of European military expeditions to the Holy Land. The Latin Kingdom of Jerusalem had been established in 1099, and King Sigurd was received by the first king of the crusader state, Baldwin I, upon arriving in Palestine. En route to Jerusalem, Sigurd fought several battles, mainly against local rulers in Muslim Spain and Moorish pirates. While in the Holy Land he assisted King Baldwin in conquering the town Sidon, today's Sayda in Lebanon.

King Sigurd's crusade is described in several written sources from the Middle Ages. The best known is The Saga of the Sons of Magnús [Magnussønnenes saga] by the Icelandic historian, poet, and chieftain Snorri Sturluson (1179-1241). The saga was written around 1220-1235 and is part of his book Heimskringla, where he presents the lives of Norse kings. ${ }^{2}$

The two tapestries were based on paintings by Gerhard Munthe (1849-1929), and were woven by the workshop The Norwegian Tapestry Weaving Company [Det norske Billedvæveri], led by artist and weaver Frida Hansen (1855-1931). Gerhard Munthe and

1 See Chapter 6 (Pål Berg Svenungsen), vol. 1, 95-131.

2 Snorri Sturluson and C. R. Unger, Heimskringla, eller Norges kongesagaer (Christiania: Brøgger \& Christie, 1868), 325.

Torild Gjesvik, PhD, Independent Scholar, Oslo, Norway 


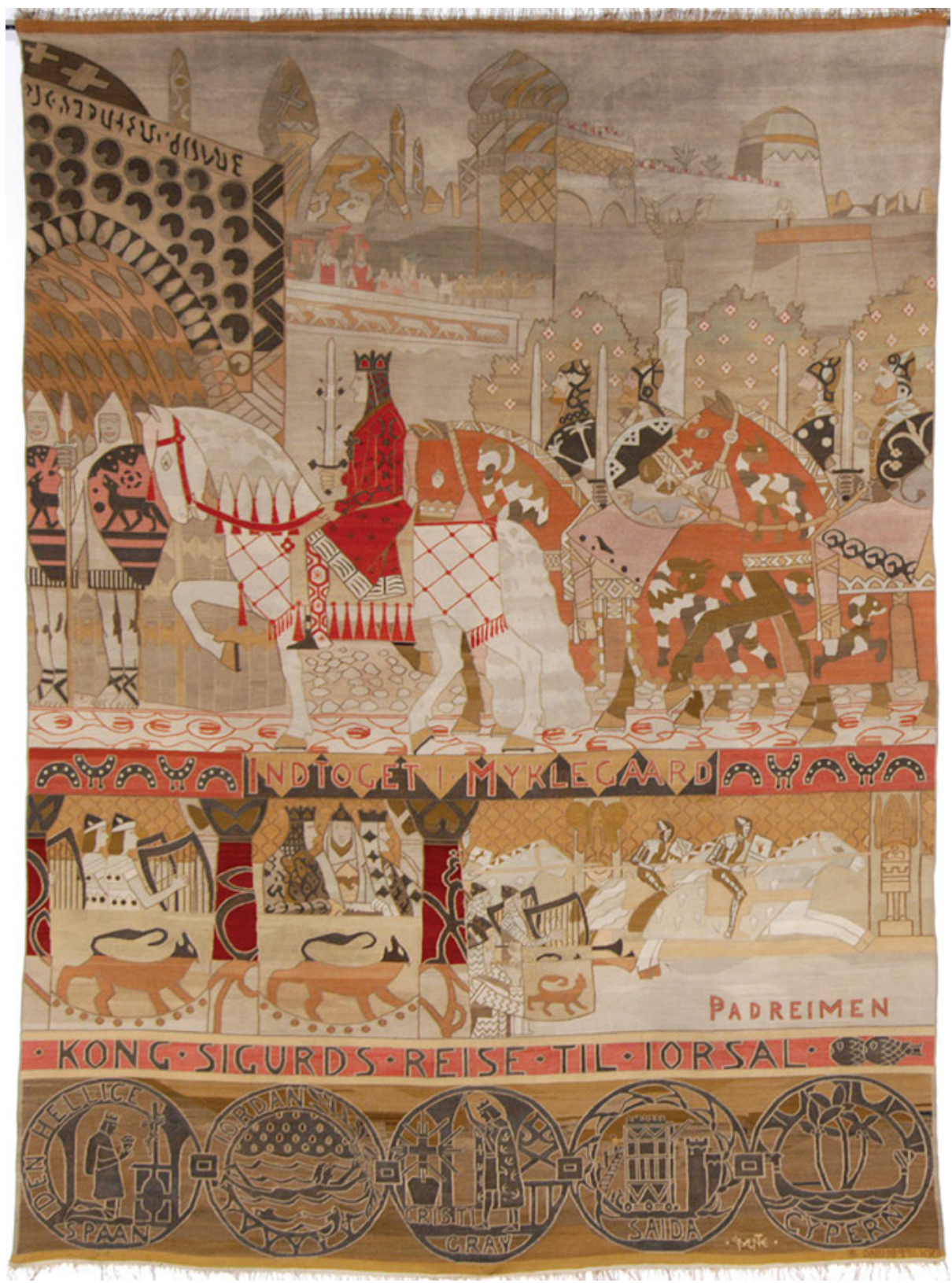

Fig. 28.2: The Entry into Miklagard, 1900. Tapestry made by The Norwegian Tapestry Weaving Company/Det norske Billedvæveri. 452 x $336 \mathrm{~cm}$. The Royal Palace, Oslo. Photo: Kjartan Hauglid, De kongelige samlinger. 


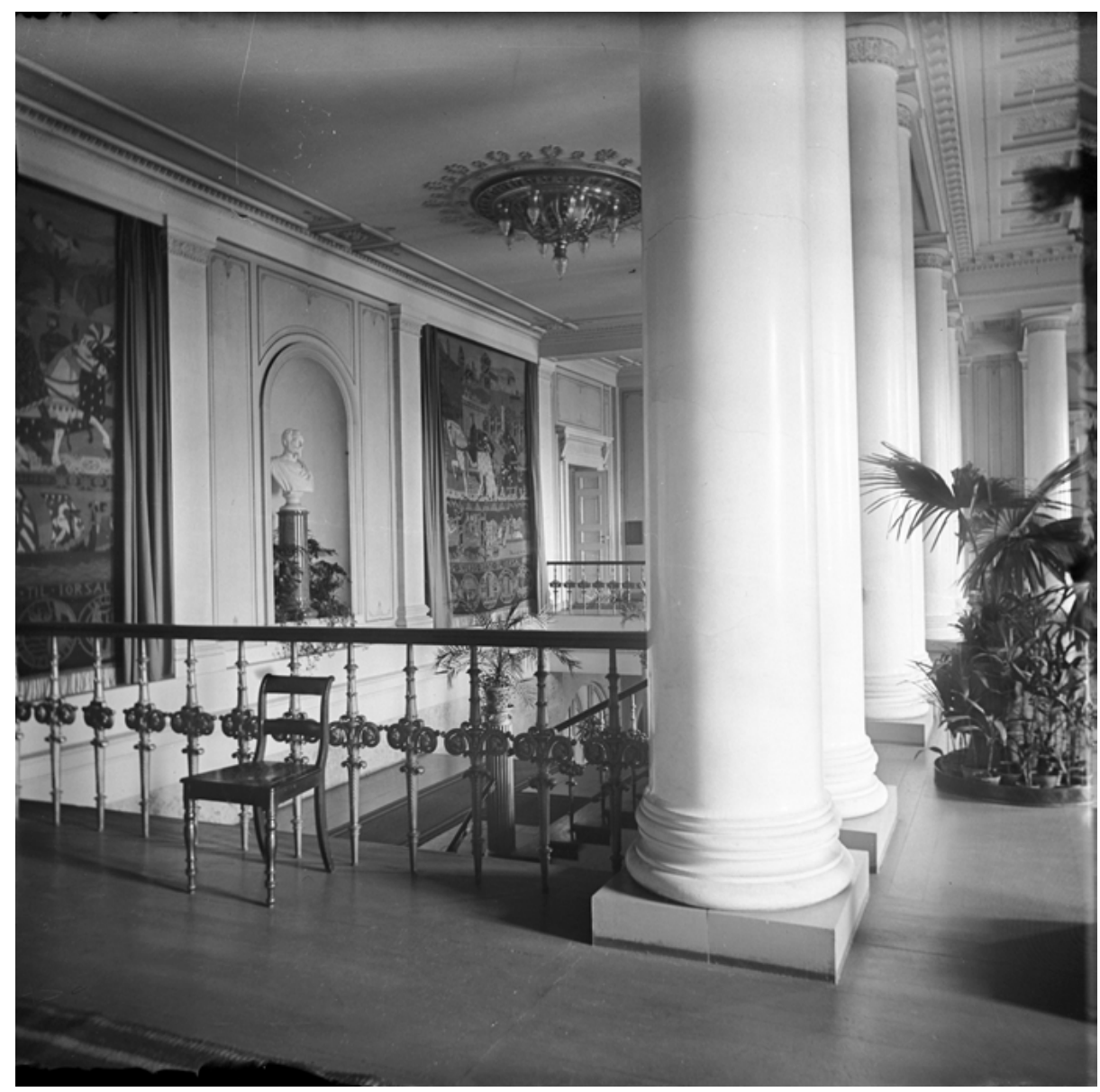

Fig. 28.3: The National Tapestries displayed in the main staircase of The Royal Palace, Oslo. Photo: Severin Worm-Petersen, Det kongelige slott. The Norwegian Museum of Science and Technology.

Frida Hansen were both among the most prominent Norwegian artists of their generation. The tapestries were exhibited at the Exposition Universelle in Paris in 1900, where they earned a gold medal. The same year the tapestries were named The National Tapestries [Riksteppene] - a title that is still used today - thus asserting their particular national relevance. It was argued that these tapestries must be secured for the nation and their destiny was debated in the Norwegian Parliament and in newspapers. Eventually they were bought by private means and donated to the Royal Palace. For almost a century they hung in the main staircase/vestibule, thus amounting to a prelude for visitors entering the Palace (Fig. 28.3). 


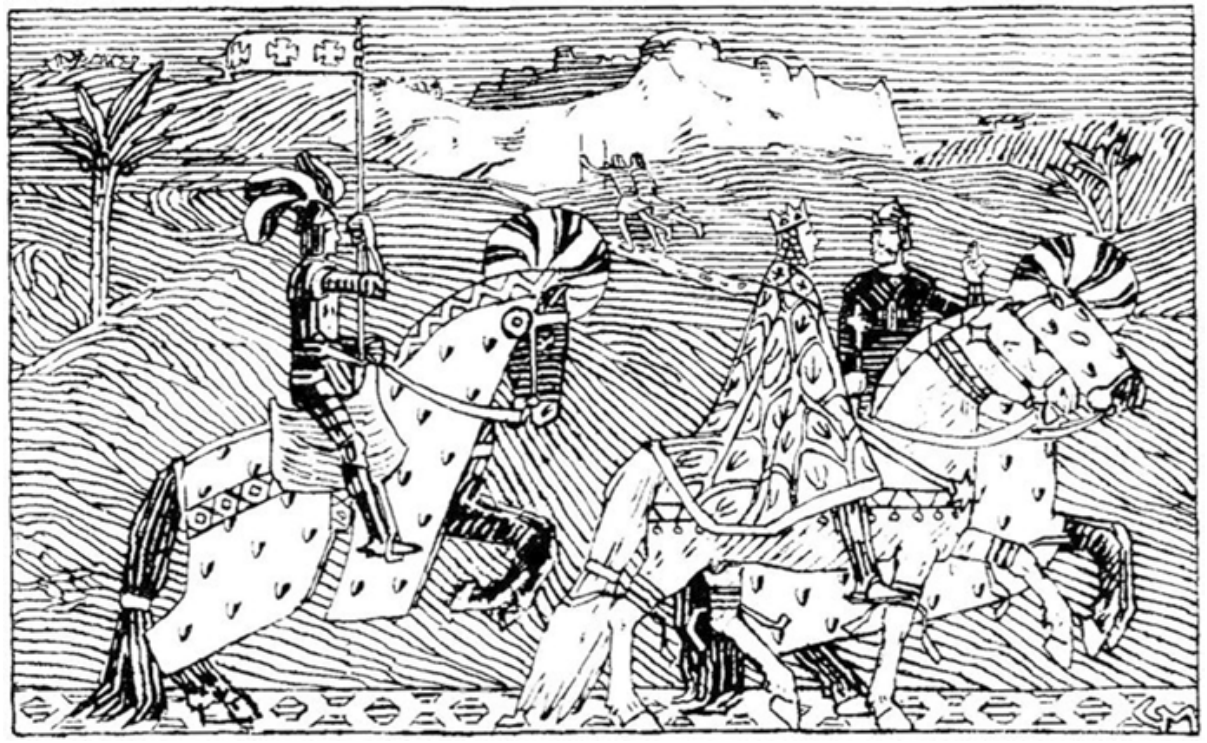

Fig. 28.4: Gerhard Munthe, King Sigurd and King Baldwin Riding from Jerusalem to the Jordan River. Illustration from Snorri Sturluson, Heimskringla, 1899.

How did the images of a medieval king, on a rather bloodstained journey to Jerusalem, come to be seen as an apt representation for the Norwegian nation around 1900? From today's perspective, the idealization of Sigurd the Crusader might seem somewhat surprising. Norway tends to promote itself as a peace-loving nation, and for several decades it has mediated international peace negotiations, including in the Middle East. In this article I explore Gerhard Munthe's images of Sigurd the Crusader in Jerusalem and Constantinople, and inquire into how the tapestries came into being. I also discuss their reception, and how they gained their status as national tapestries and were linked to the quest for a national identity and sovereignty.

The tapestries can be seen as bringing together different layers of time: the early twelfth century when Sigurd the Crusader travelled to Jerusalem; the early thirteenth century when Snorri Sturluson wrote his saga; and the years around 1900 when Gerhard Munthe took up the motif of Sigurd's crusade. At that time, Norway was in a union with Sweden, and did not have full national independence. ${ }^{3}$ Over the years, the story of Sigurd the Crusader has been told in different ways and in different media. In the case of The National Tapestries artistic, cultural, and political matters are shown to be closely intertwined. This case also illuminates how contemporary concerns have been woven into changing perceptions of Sigurd.

3 For a discussion of Norway's union with Denmark, followed by the union with Sweden, see below. 


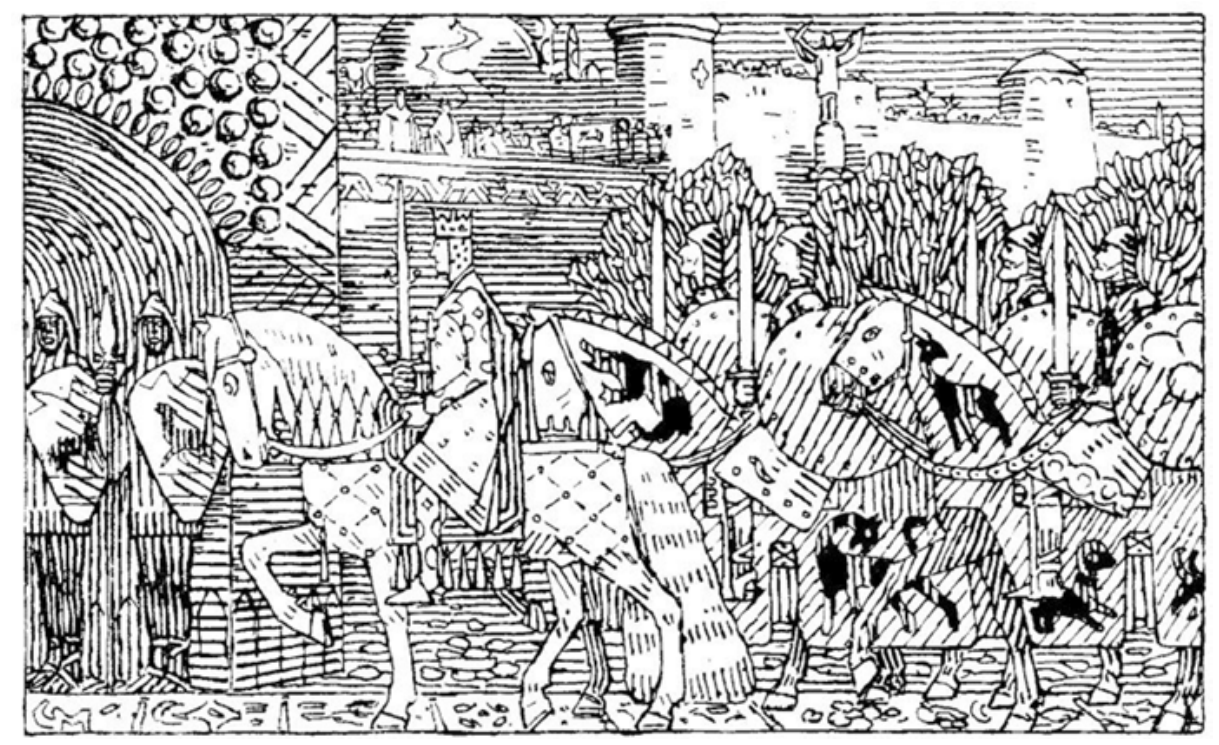

Fig. 28.5: Gerhard Munthe, The Entry into Miklagard. Illustration from Snorri Sturluson, Heimskringla, 1899.

\section{King Sigurd's Crusade According to Gerhard Munthe and Snorri Sturluson}

Let us first scrutinise how Munthe worked with the motifs of King Sigurd in Jerusalem and Constantinople. How does he portray the king, and how does he tell the story of Sigurd's crusade? Munthe's main source of inspiration was The Saga of the Sons of Magnús. King Magnús Barefoot reigned in Norway 1093-1103 and had three sons: Eystein, Sigurd, and Olav. After King Magnús's death, Norway was divided between the three. Because Olav was only a small child, the elder brothers Eystein and Sigurd were to rule his part.

The first part of the saga narrates the story of King Sigurd and his crusade to the Holy Land. Snorri Sturluson writes that the brothers agreed to outfit a journey, and decided that Sigurd should go while Eystein should rule the whole country in his absence. "Four years after the death of King Magnús, King Sigurth and his expedition left Norway. He had with him sixty ships." ${ }^{4}$ About three years later, he

4 Snorri Sturluson, Heimskringla: History of the Kings of Norway, 2nd paperback print, trans. Lee M. Hollander (Austin: University of Texas Press, 1995), 689. In Lee M. Hollander's translation of the saga, Sigurd is spelled Sigurth. I have used the modern Norwegian spelling - Sigurd - in the article, except when I cite Hollander. 
reached Jerusalem. Sigurd was only about eighteen years old when he left Norway with his fleet. $^{5}$

In 1899 a new, richly illustrated edition of Heimskringla was published in Norway. ${ }^{6}$ Gerhard Munthe was responsible for the book's overall visual design, including borders, ornaments, and vignettes, and he also contributed a substantial number of illustrations. This edition of Heimskringla is regarded as one of the high points of Norwegian book design and as a prominent example of art nouveau.

One of the illustrations for The Saga of the Sons of Magnús represents King Sigurd and King Baldwin riding together from Jerusalem to the Jordan River (Fig. 28.4). King Baldwin had been one of the leaders of the first crusade, and had become the first king of The Latin Kingdom of Jerusalem in 1100. Another illustration represented King Sigurd's entrance into Constantinople, or Miklagard - meaning "the great city" - as it was called in Old Norse (Fig. 28.5). These illustrations mark the starting point for Munthe's interest in the two motifs. Having finished his drawings for the book, he made two considerably larger and more extensive versions in tempera painting (Figs. 28.6 and 22.0) The tapestries were based on these paintings and were finished the year after, in $1900 .^{7}$ In the two tempera paintings, the story of King Sigurd's crusade is elaborated in some detail. Munthe took his cues from Snorri Sturluson's text, and the different scenes in the paintings visualize important moments in the saga.

The paintings are conceived as a pair. Compositionally they are both divided into three parts, separated by decorative borders. The two main motifs closely resemble Munthe's illustrations for the saga, and are explained in the titles inscribed below: Sigurd og Balduin [Sigurd and Baldwin] and Intoget $i$ Myklegaard [The Entry into Miklagard]. ${ }^{8}$ Below the main motifs, Munthe has chosen two other important scenes from the saga. The painting of Sigurd and Baldwin includes an image of King Sigurd's fleet leaving Norway, which is another reworked version of one of Munthe's illustrations in The Saga of the Sons of Magnús. The scene below King Sigurd's entrance into Miklagard refers to his visit to the hippodrome (called Padreimen in the saga) in Constantinople, where he was invited by the Byzantine emperor Alexius I Comnenus. ${ }^{9}$

5 Sigurd was born around 1090, but his exact birthdate is unknown.

6 Snorri Sturluson, Gustav Storm and Halfdan Egedius, Kongesagaer (Kristiania: J. M. Stenersen, 1899).

7 Jens Thiis, Gerhard Munthe: en Studie (Trondhjem: Aktietrykkeriet, 1903), 34.

8 I generally use the modern Norwegian spelling Miklagard. Myklegaard, the spelling used in Munthe's time, is used in citations, such as this one. Similarly, King Baldwin was spelt Balduin in Munthe's time.

9 Alexius I Comnenus, Byzantine emperor 1081-1118. In the The Saga of the Sons of Magnús he is named Kirjalax. 


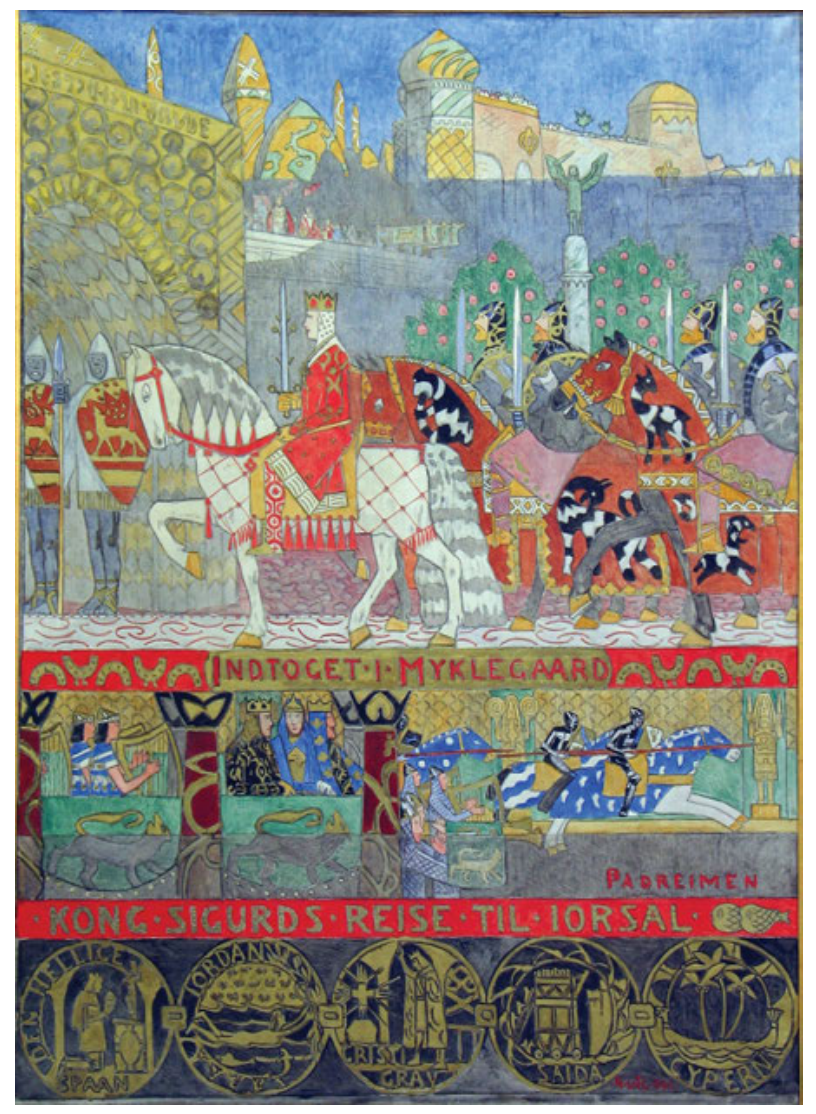

Fig. 28.6: Gerhard Munthe, The Entry into Myklagard, 1899. Tempera, $143 \times 103 \mathrm{~cm}$. (c) Trondheim kunstmuseum. Photo: Ute Freia Beer.

I return to some of the iconographical details of these larger images, but let us first scrutinise the medallions in the lower part of the paintings (Figs. 28.7 and 28.8). These smaller images, formed as emblems, are headed by the text "Kong Sigurds reise til Jorsal" [King Sigurd's Journey to Jerusalem], and represent other crucial episodes from Sigurd's crusade. Except for one, all refer to scenes from the saga. The medallions are arranged chronologically, from left to right, and narrate in condensed form the journey of King Sigurd.

\section{The Narrative of the Emblems}

In the Sigurd and Baldwin tempera painting the image of the first medallion is an equestrian motif (Fig. 28.7). The man on horseback, carrying a shield and a raised sword, is accompanied by the inscription "HENRIC REX." It refers to the first stop on King Sigurd's journey, and his visit to Henry I, King of England. Snorri Sturluson 


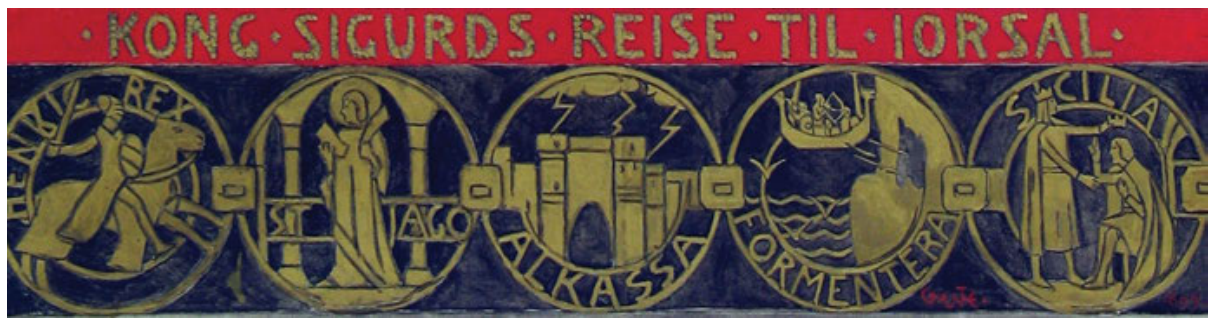

Fig. 28.7: Gerhard Munthe, Sigurd and Baldwin. (Detail, Fig. 22.0).

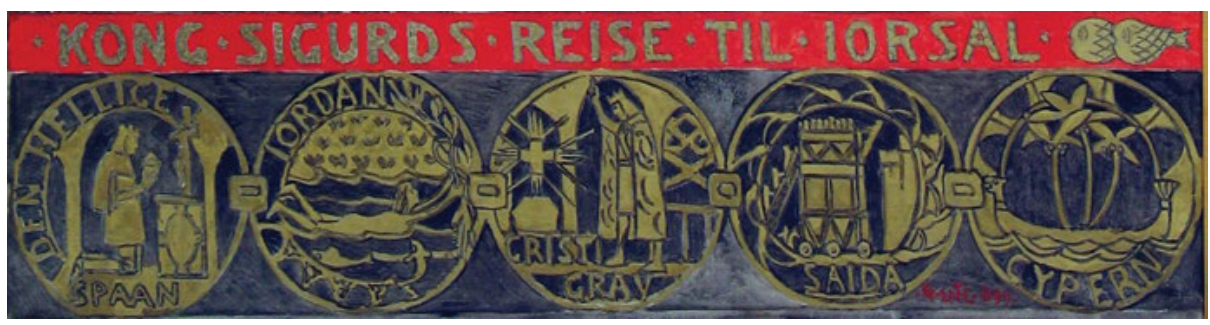

Fig. 28.8: Gerhard Munthe, The Entry into Miklagard. (Detail, Fig. 28.6).

writes: "In the fall King Sigurth sailed to England. At that time Henry, the son of William the Bastard, was king. King Sigurth remained there during the winter."10 In spring, Sigurd and his men moved on and reached Galicia (part of today's Spain) in the autumn. The second image represents Saint James - as indicated by the inscription "St Jago" - and alludes to the king's visit to one of the main pilgrim sites in Europe, Santiago de Compostela. According to the saga, Sigurd spent most of the winter in Galicia before sailing onwards along the coast of today's Portugal. En route he fought his first three battles against "the heathens."11 The third medallion shows a fortress being struck by lightning (as a sign of God's holy wrath visited

10 Sturluson, Heimskringla: History of the Kings of Norway, 689.

11 In Lee M. Hollander's translation of the saga, the word "heathens" is used about the adversaries of Sigurd. Most of the heathens that Sigurd encountered would have been Muslims. On terminology, see Bjørn Bandlien, "Images of Muslims in Medieval Norway and Iceland," in Fighting for the Faith - the Many Crusades, eds. Kurt Villads Jensen, Carsten Selch, and Janus Møller (Stockholm: Sällskapet Runica et mediævalia, Centre for Medieval Studies, Stockholm University, 2018), and Chapter 6 (Pål Berg Svenungsen) vol. 1, 95-131. See also Øystein Morten, Jakten på Sigurd Jorsalfare (Oslo: Spartacus, 2014), 94-107. Morten critically traces King Sigurd's journey as it is told by Snorri Sturluson. He also discusses the complex religious constellations in parts of today's Spain and Portugal at the time of Sigurd's crusade. In my article I will not discuss the historical correctness, or lack thereof, in the saga. My focus is rather how the text of the saga is interpreted and used by Gerhard Munthe. 
upon the heathen men?), and refers to the battle at Alcasse. ${ }^{12}$ In his laconic style, Snorri Sturluson writes: "Then King Sigurth with his fleet proceeded west [south] along the heathen part of Spain and made land by a city which is called Alcasse, and there had a fourth battle with the heathens and conquered that city. He slew many people there so as to depopulate the city. There they made an immense amount of booty."13

The somewhat strange image of the fourth medallion of the Sigurd and Baldwin painting, showing a ship hovering in the air, refers to one of the most discussed episodes of Sigurd's journey. The king had passed through Norvasund (the Old Norse name for The Strait of Gibraltar), sailed along the coast of Serkland (here probably meaning the coast of North Africa) and reached Formentera, the smallest of the Balearic Islands. "There a large force of heathen black men had established themselves in some cave and had placed a stone wall in front of its mouth."14 Snorri Sturluson writes that these "heathen" men had "harried far and wide on the land and had brought all their booty into the cave." "King Sigurd and his men tried to conquer the island, but the cave was situated high up on a steep hillside, and "the heathens" could easily defend themselves by hurling stones or shooting down at the Norsemen. The saga continues: "Then the heathens brought costly stuffs and other precious things out on the wall, shook them at the Norwegians, shouted at them, egged them to come on, and taunted them." ${ }^{\text {16 }}$ King Sigurd responded by making a sly plan:

He had two ship-boats which are called barks [launches] dragged up to the top of the cliff above the opening of the cave and had them secured with strong ropes under the ribs and the stern. Then as many men got into them as could find room in them, and then they let the boats down above the cave with ropes. ${ }^{17}$

This is the moment Munthe has chosen to represent. The men in the boats could now attack "the heathens" who fled into the cave. King Sigurd then built a fire in the cave's opening, and consequently "the heathens" were either burnt to death or slain. Snorri Sturluson concludes: "The Norwegians took the greatest amount of booty they had gotten on this expedition."18

The last medallion in the Sigurd and Baldwin painting refers to King Sigurd's visit to Sicily. According to the saga, he was greeted by Duke Roger, and after seven days of feasting together, "King Sigurth took the duke by the hand, led him up to the high-

12 Identified by Morten as Alcacer do Sal in today’s Portugal. Morten, Jakten på Sigurd Jorsalfare, 103.

13 Sturluson, Heimskringla: History of the Kings of Norway, 691.

14 Sturluson, Heimskringla: History of the Kings of Norway, 692.

15 Sturluson, Heimskringla: History of the Kings of Norway, 692.

16 Sturluson, Heimskringla: History of the Kings of Norway, 692.

17 Sturluson, Heimskringla: History of the Kings of Norway, 692.

18 Sturluson, Heimskringla: History of the Kings of Norway, 693. 
seat, and conferred the title of king on him and the right to be king over the realm of Sicily; but before that time earls had ruled that land." ${ }^{19}$ Snorri Sturluson relates that after having left Sicily, Sigurd sailed to Palestine, landed at the seaport Acre, and went overland to Jerusalem, where he was received by King Baldwin.

In these five medallions, in the Sigurd and Baldwin painting, King Sigurd's victories are emphasized as well as his authority as king. Even the format of the medallions serves to underscore this point: they might recall royal signet rings. King Sigurd meets on equal terms with other kings and even has the authority to bestow royal authority onto others. Sigurd as a Christian king and the mission of the crusade is implied in the reference to Saint James, and is the main theme of the medallions represented in the painting of Sigurd's entrance into Constantinople, The Entry into Miklagard.

The first three emblems of The Entry into Miklagard tempera painting show key moments from the king's visit to Jerusalem (Fig 28.8). The image of the king kneeling in front of a crucifix, surrounded by the text "Den hellige spaan" [The Holy Splinter], refers to Sigurd's receiving a chip of the Holy Cross as a relic. "With the consent of King Balduin and the Patriarch a splinter was taken from the Holy Cross. They both swore by the sacred relics that this wood was from the Holy Cross on which God himself was martyred." ${ }^{20}$ This precious relic was received on several conditions: King Sigurd and twelve of his men had to swear that they would: "promote Christianity with all his power and establish an archbishopric [in his land] if he could, and that [this piece of] the cross should be deposited where Holy King Óláf was interred, and that he [the king] should promote the paying of tithes [to the church] and that he should do so himself." ${ }^{21}$ King Sigurd did not fulfil all these obligations, but according to tradition, the relic was taken back to Norway. ${ }^{22}$

The next scene shows the king's ritual bath in the Jordan River and alludes to the baptism of Christ by St John. Snorri Sturluson explains that the two kings rode together to the river and then back to Jerusalem, and cites the bard Einar Skulason, who says that Sigurd "bathed in blessed Jordan's/burn, of sin to cleanse him."23 The third medallion represents King Sigurd visiting the tomb of Christ. This episode is not explicitly mentioned in the saga, but is found in other sources. ${ }^{24}$ While staying in Palestine, Sigurd and his men accompanied King Baldwin and his army to Sidon (today's Sayda): “That city was heathen. . . . And when the two kings had

19 Sturluson, Heimskringla: History of the Kings of Norway, 694. Roger was Grand Count of Sicily (1105-1130), and then Roger II King of Sicily (1130-1154). For a discussion of the historical inaccuracies of the saga on this point, see Morten, Jakten på Sigurd Jorsalfare, 124-5.

20 Sturluson, Heimskringla: History of the Kings of Norway, 696.

21 Sturluson, Heimskringla: History of the Kings of Norway, 696.

22 For additional information about this relic, see Chapter 6 (Pål Berg Svenungsen), vol. 1, 95-131.

23 Sturluson, Heimskringla: History of the Kings of Norway, 696.

24 Fulcher of Chartres and Albert of Aix/Aachen. 
beleaguered the city for a short time the heathen men surrendered, and the kings took possession of the city, and their troops of all other booty. King Sigurth yielded to King Balduin entire possession of the city." 25 Snorri Sturluson cites the bard Haldór Skvaldri: "Heathen fastness, feeder-of-/famished-wolves, thou tookst and,/ great-hearted, gavest back then,/gallant ruler, to Balduin." 26 The image shows a belfry (siege tower), which was used in medieval warfare.

After leaving Palestine, Sigurd went to Cyprus which, according to the inscription "Cypern," is the theme of the last medallion of The Entry into Miklagard painting. It shows a ship and palm trees. Palm trees, and palm sprigs, are common Christian pilgrim symbols. Here they also add a paradisiacal flavour to this place of rest, where - the saga tells us - Sigurd stayed for some time before going on to Greece and Constantinople.

\section{Munthe's Vision of King Sigurd in Jerusalem and Constantinople}

Having followed the narrative of the medallions, it is time to return to the main motifs of the paintings. What image of King Sigurd does Munthe create, and how does he represent Jerusalem? Gerhard Munthe had never been to the Holy City himself, and the visual sources he might have used as inspiration in portraying Jerusalem are uncertain. The painting of Sigurd and Baldwin shows a hilly, desert-like landscape (Fig. 22.0). A few date palms, olive trees(?), and the caravan in the background add an exotic touch to the scene. On top of the hill lies Jerusalem. We can see parts of the city walls, and what appears to be the Dome of the Rock.

Although Munthe's representation of the Holy City is highly stylized, it is recognizable as Jerusalem. The main features of the landscape - the hills and the situation of the city - can be seen in other contemporary images of Jerusalem. One example is the picture reproduced in the Norwegian priest Birger Hall's book Fra Østen. Reiseerindringer fra Egypten, Syrien og Palæstina [From the East. Travel Recollections from Egypt, Syria and Palestine] from 1888 (Fig. 20.2). ${ }^{27}$ Another

25 Sturluson, Heimskringla: History of the Kings of Norway, 696.

26 Sturluson, Heimskringla: History of the Kings of Norway, 696.

27 Birger Hall, Fra Østen. Reiseerindringer fra Ægypten, Syrien og Palæstina (Kristiania: P.T. Mallings Boghandels Forlag, 1888), 132. Hall does not state the name of the artist or from where he has taken this picture. However, the same picture was reproduced in Johan Storm Munch's Minder fra en Jerusalemsfærd (Kristiania: P.T. Mallings Boghandels Forlag, 1884), 30. Munch states that he has borrowed the image from Christopher Andreas Holmboe, Bibelsk Real-Ordbog (Chrstiania: Mallings Forlagsboghandel, 1868). So far I have not traced this particular image of Jerusalem any further, but it is interesting to note its reuse. Perhaps Holmboe borrowed it from an international source. On Hall and Storm Munch's journeys, see Chapter 20 (Birger Løvlie), 410-29. 


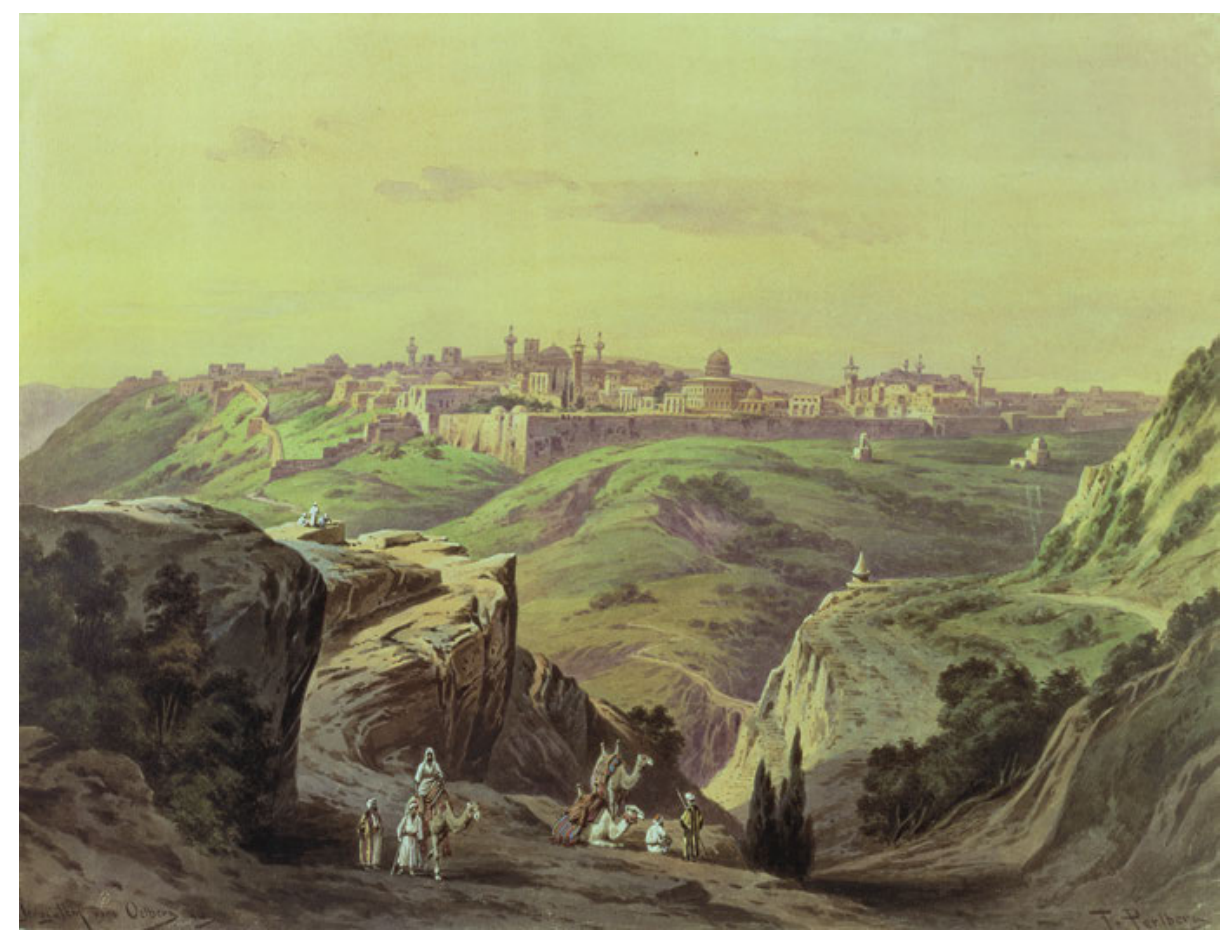

Fig. 28.9: Friedrich Perlberg, View of Jerusalem, c.1898. Water colour on paper. Private Collection / Photo $\odot$ Christie's Images / Bridgeman Images.

example is the German artist Friedrich Perlberg's painting "View of Jerusalem," which includes exoticizing details such as camels, and their tenders dressed in long tunics (Fig. 28.9). ${ }^{28}$

28 Friedrich Perlberg was Munthe's contemporary and they might have known each other from Munich, where they both lived for some years. Perlberg followed Wilhelm II, Emperor of Germany, on his visit to the Holy City in 1898. Some of his paintings from this visit were reproduced as postcards. The emperor's visit to Jerusalem was mentioned in Norwegian newspapers at the time, but so far I have not been able to trace any illustrated articles in the Norwegian press. It is tempting to speculate that Munthe might in some way have been inspired by pictures made in relation to the emperor's visit. However, it is uncertain when Munthe actually finished his illustrations for The Saga of the Sons of Magnús: Heimskringla was published in several volumes from 1896 to 1899, and Munthe might or might not have finished his pictures of Sigurd before the emperor's visit. I thank Jan Kokkin for sharing his findings with me on this point. It should also be added that Perlberg's painting has much in common with the illustration printed in Hall's book. 
In the Sigurd and Baldwin painting, in the foreground, as on a stage, King Sigurd and King Baldwin are riding (Fig. 22.0). The Norwegian king stands out in his richly decorated red cloak. He is wearing a crown and a chainmail hood and is carrying a cross. His white horse with red harness is a convention used in several medieval representations of the crusaders. ${ }^{29}$ King Baldwin looks at, and gestures to his guest. Judging by the green caparisons of the other two horses, the kings are accompanied by one of King Baldwin's knights. The ornamental road in the foreground continues uphill where two men, carrying some sort of sticks, are running. These men are not mentioned in the saga, but art historian Hilmar Bakken identifies them as messengers. ${ }^{30}$

According to Snorri Sturluson, the Norwegian king was welcomed with honour: "King Balduin received King Sigurth most graciously and with him rode to the River Jordan and back to Jerusalem." ${ }^{31}$ This is the moment that Munthe has chosen as the main motif of the painting. In the narrative of the saga and in Munthe's interpretation of the scene, the authority of King Sigurd is strongly emphasized. He is received as a distinguished guest and the two kings are portrayed as equals.

Demonstrating the king's authority is an important aspect of the other painting as well. In The Entry into Miklagard, Munthe has chosen to represent the king about to enter Constantinople (Fig. 28.6). In Snorri Sturluson's narrative, Sigurd is allowed to enter through Gullvarta [Golden Gate] which was the Emperor's gate of victory: "Also Emperor Kirjalax had heard of the approach of King Sigurth, and he had the castle gate of Miklagarth opened which is called Gullvarta (Golden Gate). That gate the emperor is to ride through when he has been away for a long time from Miklagarth and returns victorious." 32

The painting is overwhelmingly rich in colours and details. The architecture appears to be a kind of oriental fantasy with minaret-like towers and onion domes. Munthe had not been to Constantinople, but as he included a column with a Winged

29 See for example the plan of Jerusalem from about 1200, “Picture Bible, Psalter Fragment?” from St. Omer, Benedictine Abbey of St. Bertin, c.1190-1200, in Medieval Illuminated Manuscripts, The Hague KB, 76 F 5, fol. 1r sc. 1 and 2, National Library of the Netherlands. Koninklijke Bibliotheek, Nationale bibliotheek van Nederland, accessed May 5, 2018, http://manuscripts.kb.nl/show/ images $/ 76+F+5$. And Jean Colombe's miniature of the battle of Dorylaeum in Sébastien Mamerot: Les Passages d'Outremer from c.1474. Wikipedia, "Bataille de Dorylée. Miniature de Jean Colombe tirée des Passages d'outremer de Sébastien Mamerot, BnF Fr 5594, f.37v.,” accessed May 25, 2018, https://fr.wikipedia.org/wiki/Alexis_Ier_Comnène\#/media/File:Passages_d\%27outremer_-_BNF_ Fr.5594,_f37v_-_bataille_de_Dorylée.jpg. It is not known from which sources Gerhard Munthe picked up this convention.

30 Hilmar Bakken, Gerhard Munthes dekorative kunst (Oslo: Gyldendal, 1946), 163. So far, I have seen no other references to these two figures, and it is not clear if Bakken's identification is his own interpretation or if he has this information from other sources.

31 Sturluson, Heimskringla: History of the Kings of Norway, 695.

32 Sturluson, Heimskringla: History of the Kings of Norway, 698. 
Victory statue, he had probably heard of the Column of Marcian. This Column was erected during the fifth century and has served as an important landmark in the city.

According to the saga, the street, from the gate all the way up to the Royal Palace, had been covered with costly textiles. King Sigurd instructed his men "to ride into the city with a proud bearing and not to show any astonishment at all the new things they might see." 33 In Munthe's representation, Sigurd is leading his men towards the gate, where the emperor's guards are waiting. Once again Sigurd stands out in his red robe. The robe as well as the red harness of his white horse has been changed since his visit to Jerusalem. His men look straight ahead and are holding their swords erect. Their horses carry red caparisons adorned with various fantastic beasts.

During Sigurd's visit to Constantinople, the emperor continued to bestow honours on the Norwegian king. So says the saga. At one point, the emperor sent some of his men to King Sigurd and asked if he preferred to receive six hundredweights of gold, or to have the emperor arrange games in the hippodrome. King Sigurd preferred the latter, and the games were arranged according to custom. This is the other scene from Constantinople that Munthe has chosen as a motif. Sigurd is seated together with the emperor and the empress, looking at the racing horses. The games are accompanied by music from harps and various wind instruments.

Both the saga and Munthe's images present King Sigurd as a hero. However, there are also striking differences in the way they portray the king. In the saga, Sigurd's battles are the main focus of the narrative covering the voyage from Norway to the Holy Land, and Sigurd is presented as a successful crusader and warrior. The king and his army's slaying of religious opponents and their taking of booty are told matter-of-factly and as a self-evident part of the crusade's purpose. Munthe - on the other hand - plays down this violent aspect of King Sigurd's expedition, and in the medallions only hints at some of the battles. In the saga, Eystein is said to have ruled Norway admirably in Sigurd's absence, and yet Sigurd stands out as the hero who ventured out and was received on a par with the great rulers of the Holy City and of Constantinople. It is exactly the Norwegian king's proud performance on the world stage which is emphasized in Munthe's images. ${ }^{34}$

33 Sturluson, Heimskringla: History of the Kings of Norway, 698.

34 After Sigurd's return to Norway, the saga tells a more complex story of his character and of the strained relationship between the two brothers Eystein and Sigurd. Sigurd is portrayed as having a dark and troubled mind, verging on madness. However, such complexities are not hinted at in Munthe's visual version of the story. 


\section{The Middle Ages as Norway's Golden Age}

While eighteenth-century scholars such as the French Enlightenment philosopher Voltaire and the British historian Edward Gibbon were deeply sceptical towards the Crusades, and saw them as morally corrupt, the conception of the Crusades and the crusaders changed during the following century. The British ecclesiastical historian Jonathan Riley-Smith connects this changed and more positive approach with nineteenth-century imperialism, and with the renewed appreciation of the Middle Ages. ${ }^{35}$ The heroizing of the crusaders was a European phenomenon, and in this respect Munthe's images were part of a wider trend. ${ }^{36}$

The heroizing of Sigurd the Crusader was also connected to specific historical and political circumstances in Norway. From the late fourteenth century, Norway had been in union with Denmark and Sweden, the so-called Kalmar Union. After its dissolution, Norway became a dependency under Denmark from 1537 until 1814. After the Napoleonic Wars, Denmark, which had supported Napoleon, was forced to cede Norway to Sweden under the 1814 Treaty of Kiel. Norway managed to adopt its own constitution the same year, but continued to be in union with Sweden until 1905.

Within the union with Sweden, Norway was granted a high degree of autonomy, with its own parliament, government, and prime minister. However, Sweden controlled Norway's foreign policy, and the Swedish king was also king of Norway. The relationship between the two countries varied from relative harmony to considerable tension. During the 1890s, the Norwegian government challenged Sweden and demanded control over its own foreign policy and the establishment of independent consulates. ${ }^{37}$ The special appeal of Sigurd the Crusader around this time testifies to a desire to reestablish Norway as a proud and independent nation in the world.

Gerhard Munthe was not the first artist to be fascinated by Sigurd. In 1872 Bjørnstjerne Bjørnson - one of Norway's most prominent poets - had published his historical drama Sigurd Jorsalfar, inspired by The Saga of the Sons of Magnús. ${ }^{38}$ The composer Edvard Grieg contributed a work of incidental music - Sigurd Jorsalfar (Opus 22) - for the drama's premiere at Christiania Theatre the same year. When the National Theatre opened in 1899 in Kristiania (today’s Oslo), Bjørnson's drama, accompanied by a revised version of Grieg's music, was performed as one of three

35 Jonathan Riley-Smith, The Crusades, Christianity, and Islam (New York: Columbia University Press, 2008), 336.

36 Elizabeth Siberry, The New Crusaders: Images of the Crusades in the Nineteenth and Early Twentieth Centuries (Aldershot: Ashgate, 2000).

37 Store norske leksikon, “Unionsoppløsningen i 1905," accessed November 6, 2017, https://snl. no/Unionsoppl\%C3\%B8sningen_i_1905.

38 Bjørnson's play is not explicitly about Sigurd's Crusade. Its main focus is the relationship between the two brothers after Sigurd's return to Norway. 
plays marking this important national event. ${ }^{39}$ The same year, the new edition of Heimskringla was published, and Munthe made his paintings of Sigurd the Crusader. The tapestries were finished in 1900.

The growing awareness of King Sigurd, peaking around the turn of the century, was also part of a general interest in the Middle Ages. Medievalism - a strong European trend - was in Norway connected to the search for a national identity which characterized much of the nineteenth century and was closely related to the struggle for national independence. ${ }^{40}$ The centuries under Danish supremacy were commonly referred to as "the night of 400 years," reflecting the negative view long associated with this period of Norwegian history. ${ }^{41}$ In order to establish firm ground for a national identity, the Norwegian elite harked back to the Viking Age and the Middle Ages, when Norway had been an independent kingdom. These periods were conceived of as Norway's golden ages. ${ }^{42}$ In the quest for a national identity, the Norwegian freeholding peasants played a significant role. Unlike in many other countries, serfdom did not exist, and many Norwegian peasants owned and farmed their own land. In several parts of the country, old traditions, such as building techniques and dress practices, persisted, and thus the Norwegian peasant was conceived of as representing a strong, direct link to the Middle Ages.

The 1880 excavation of the Gokstad ship, a well-preserved Viking Age ship burial, contributed to the interest in and idealization of Norway's early history. Munthe's

39 The play was staged six times between 1899 and 1914. The high frequency of performances during these years, before and after the dissolution of Norway's union with Sweden in 1905, confirms the importance of Sigurd the Crusader as a national symbol during this period. Since then, it has been put on only once by the National Theatre. That was in 1944, under the German occupation of Norway. Nationaltheatret Arkiv, "Produksjoner," accessed October 13, 2017, http://forest.nationalth eatret.no/Productions/Index/?as_tit=SIGURD\%20JORSALFAR.

40 See for example Bjarne Hodne, Norsk nasjonalkultur: en kulturpolitisk oversikt (Oslo: Universitetsforlaget, 1995). On the international phenomenon of medievalism, see for example David Matthews, Medievalism: A Critical History (Cambridge: D.S. Brewer, 2015), 319.

41 See Lorentz Dietrichson (Norwegian historian of art and literature): “The night of four hundred years' has become common coinage for those four centuries of Norway's history, from 1400 to 1800 , which passed between the sunset of the Haakons' and the Olafs' and the dawn of the constitutional day at Eidsvoll. And this expression has certainly proved to be justified." [“'De fire Aarhundreders Nat' er blevet et staaende Udtryk for Norges Liv i de Aarhundreder, der forløb mellem Haakoners og Olafers Soldnedgang og Ejdvoldsdagens Morgenrøde, mellem 1400 og 1800. Og dette Udtryk har ganske vist sin Berettigelse.”] L. Dietrichson, Omrids af den norske Poesis Historie: Literærhistoriske Forelæsninger: 1: Norges Bidrag til Fællesliteraturen. vol. 1 (Kjøbenhavn: Gyldendal, 1866), 1. It should be added that the conception and interpretation of the centuries under Danish rule have changed in more recent years. Translations other than those from the saga, are my own. I want to thank my husband, Svein Jarvoll, for assisting me in these translations.

42 For a discussion about this prevailing national narrative, see Kristin Bliksrud Aavitsland, "From Nationalism to Cosmopolitan Classicism: Harry Fett's Concept of Cultural Capital," Future anterior 7, no. 2 (2010): 21-5. 
representation of King Sigurd's fleet testifies to his fascination with the Viking ships. Apart from two of the sails - one adorned with the lamb and the cross, the other with an image of Christ crucified - which clearly point to the expedition as a crusade, the ships with their carved dragon-like prows appear rather like a Viking fleet.

In 1879 a woven tapestry from the Middle Ages was found when the Baldishol Church in Hedmark County was demolished. Some years later, this sensational finding came to the public's attention. The so-called Baldishol Tapestry was made between 1150 and 1190, and its rich colours had been amazingly well preserved. ${ }^{43}$ It is a fragment of a frieze, probably representing the different months of the year. The preserved fragment has been interpreted as depicting the months April and May. April is represented by a man standing next to a blossoming tree with birds; May by a warrior riding a horse. ${ }^{44}$ Its Romanesque style recalls to some extent the famous Bayeux Tapestry from the eleventh century. The finding of the tapestry contributed to a renewed interest in the Norwegian weaving tradition. An important part of this interest was the revival of the art of vertical loom weaving. In the late nineteenth century, the vertical loom was still used in some rural areas, and as we shall see, both Gerhard Munthe and Frida Hansen were greatly inspired by this particular weaving tradition.

\section{Munthe's Programme for a National Art}

Snorri Sturluson's Heimskringla had been translated into Norwegian in the sixteenth century. During the nineteenth century, public interest grew considerably and several new translations were published. ${ }^{45}$ The 1899 edition proved particularly influential. It was reprinted many times, is still found in many Norwegian homes, and is commonly referred to simply as "Snorre." In 1895 or 1896, the publisher Johan Martin Stenersen started planning this edition of Heimskringla. The historian Gustav Storm made a new translation, and Stenersen hired the painter Erik Werenskiold to be in charge of the book's visual design and illustrations. Werenskiold had distinguished himself greatly as a book illustrator by his contributions to the 1879 edition of the Norwegian folktales by Peter Christen Asbjørnsen and Jørgen Moe. Several other well-known Norwegian artists contributed illustrations for Heimskringla: Christian Krohg, Halfdan Egedius, Eilif Peterssen, and Wilhelm Wetelsen. However, Werenskiold was particularly keen to ensure Gerhard Munthe’s participation. Looking back, Werenskiold writes:

43 The Baldishol Tapestry, 1150-1190. 118 x $203 \mathrm{~cm}$. Anonymous. The National Museum of Art, Architecture and Design, Oslo. http://samling.nasjonalmuseet.no/en/object/OK-02862.

44 Aase Bay Sjøvold, Norskbilledvev. Vi ser på kunsthåndverk i Norge, vol. 5 (Oslo: Huitfeldt forlag, 1976), 7-17. See also Hans Dedekam, Baldisholtæppet (Oslo: Cammermeyer, 1918).

45 Hodne, Norsk nasjonalkultur: en kulturpolitisk oversikt, 35; Jan Kokkin, Gerhard Munthe: en norsk designpioner (Stuttgart: Arnoldsche Art Publishers, 2018), 98. 
My first priority was of course to get in touch with Munthe, asking him if he wished to take on the design of the work. He accepted the offer on the spot and with great enthusiasm. We instantly agreed on the overall character of the work; it was self-evident. Norwegian above all: simple, primitive. ${ }^{46}$

Erik Werenskiold and Gerhard Munthe were both part of a nationally minded cultural elite called Lysakerkretsen [The Lysaker Circle], so named because several of its leading figures - including Werenskiold and Munthe - lived at Lysaker, just outside Kristiania. The Lysaker Circle was not a formally organized group, but rather a more loosely formed social circle, including artists, intellectuals, and scientists, such as the polar explorer and national hero Frithjof Nansen, and Andreas Aubert, one of Norway's leading art historians. Its proponents were joined in a wish to promote and build the nation, and represented the most influential cultural political milieu in Norway around the turn of the century. ${ }^{47}$ Their confidence in this national programme is clearly expressed in Werenskiold's statement above. Significantly, he also used Frithjof Nansen as a model for the Norwegian king Olav Tryggvason (968-1000) in his own drawings for Heimskringla.

Munthe was deeply committed to creating a new national decorative art. He had been trained as a painter in Norway and Germany. For many years he painted mostly naturalistic landscapes. However, during the 1890s he started experimenting with ornamental works alongside traditional painting. The design and illustrations he made for Heimskringla are excellent examples of his new so-called decorative style. These works are characterized by a stylized, graphic expression, and emphasis is given to linear and rhythmic ornaments. Munthe practiced his decorative style not only in drawings and paintings, but also in furniture decoration and designs for everyday objects. ${ }^{48}$ The style Munthe and Werenskiold arrived at in their illustrations for Heimskringla has been termed Snorrestil [Snorri style]. To develop a new national and decorative style, Munthe considered it necessary to break with naturalism and the classic tradition. His sources of inspiration were a mix of old Norwegian art and international art, including Romanesque art, the art of the Bronze Age, Assyrian art, and Egyptian art. ${ }^{49}$

46 "var det en selvfølge at jeg først og fremst henvendte mig til Munthe og spurte om han vilde påta sig utsmykningen av verket: han grep tilbudet med begge hender og brant av iver og begeistring. Planen og verkets karakter var vi jo straks enig om; den gav sig av sig selv. Norsk fremfor alt, enkelt, primitivt.” Erik Werenskiold, “Snorre-Tegningene.” Kunst og kultur, 16 (1929): 65.

47 Bodil Stenseth, En norsk elite: nasjonsbyggerne på Lysaker: 1890-1940 (Oslo: Aschehoug, 1993), 32.

48 In this respect, there are interesting parallels between Gerhard Munthe and the originator of the British Arts and Crafts movement, William Morris. Stephan Tschudi-Madsen, "Morris and Munthe," in "Honnør til en hånet stil": festskrift til Stephan Tschudi-Madsen på 70-årsdagen, eds. Stephan Tschudi-Madsen et al. (Oslo: Aschehoug, 1993), 111-17.

49 Gerhard Munthe, Minder og Meninger: fra 1850-Aarene til Nu: med samtidige Tegninger fra Kunstnerens Samlinger (Kristiania: Cammermeyer, 1919); Kokkin, Gerhard Munthe. En norsk designpioner, 104. 
Gerhard Munthe also travelled extensively in rural Norway. He studied and was greatly inspired by Norwegian folk art, such as woodcarving, rosemaling [Rose Painting], and especially old tapestries and textiles. In many of his decorative paintings, the inspiration from traditional tapestry weaving is clearly visible. In turn, these paintings were often used as models for textiles and tapestries and were woven by female professional weavers. Munthe was hailed as the great innovator of Norwegian textile art. Many of his decorative works were inspired by Norwegian fairy tales, but occasionally his motifs were taken from Norway's history. The images of Sigurd the Crusader are the most important examples.

In Munthe's vision for a new national art, not only were the motifs to be inspired by Norwegian themes; equally - or even more - important to him was his wish to develop a national style and colour scheme. In Norwegian folk art, Munthe saw a predilection for a few strong main colours. Five colours seemed to him particularly Norwegian in character: lobster red, red-violet, traditional blue, blue-green, and yellow. In one of his essays, Munthe connects these colours to national traits and traditions. For example, he sees lobster red as representing "loud joy and straight-forwardness as opposed to the reserved," and red-violet as "stern and frightening." "50 Traditional blue - potteblå - in Norwegian, meaning "chamber-pot blue," a blue made by dyeing yarn in human urine - he sees as fresh and bold.$^{51} \mathrm{He}$ was also concerned about the combination of colours. In particular, he points out the frequent use of complementary colours in Norwegian folk art, such as the combination of red and bluish green, comparing it with "red rowanberries surrounded by green leaves" and emphasizing the active energy resulting from their combination."

The idea of regarding specific colours as expressions of national character might be hard to follow today. Yet, the colour scheme prescribed by Munthe does to some extent correspond to the colour scheme seen in the Baldishol Tapestry as well as in several other old Norwegian tapestries, such as "The Adoration of the Magi" from 1717, which Munthe saw and sketched on one of his travels. ${ }^{53}$ However, Munthe's tempera paintings of King Sigurd in Jerusalem and Constantinople show that he did not feel obliged to follow this colour scheme closely in his works. Admittedly, these paintings of Sigurd are characterized by the use of bright colours: red, blue, green, and yellow. He also uses violet in the areas of shadow in the two

50 "larmende glæde ... det Endetille, som opponerer mod det Betænkte.” Munthe, Minder og Meninger, 65.

51 Munthe, Minder og Meninger, 65.

52 Cited from Ulrike Greve, “Gerhard Munthe og den tekstile kunst," Kunst og kultur, 16 (1929): 98. See also Munthe, Minder og Meninger, 66.

53 The Adoration of the Magi. Tapestry from Gudbrandsdalen, 1717. 195 x $152.5 \mathrm{~cm}$. Anonymous. The National Museum of Art, Architecture and Design, Oslo. http://samling.nasjonalmuseet.no/no/ object/OK-01712. The sketchbook is owned by The National Library of Norway. MS Fol. 1061. The sketch is reproduced in Kokkin, Gerhard Munthe. En norsk designpioner, 59. 
paintings. In addition, he uses black and white, and gold - thus underlining the works' royal theme, perhaps also their exotic setting. However, the overall effect of the paintings is very different from that of traditional Norwegian folk art.

\section{From Paintings to Tapestries}

In the two tempera paintings of Sigurd the Crusader, Munthe reworked the small black-and-white book illustrations into large-format, colourful, and gilded paintings. By adding the medallions in the lower part of the paintings, he also managed to tell a more complete story of the crusade. Judging from the richly decorated style of the paintings, Munthe must have invested considerable time and effort in making them. Nevertheless, it was not the paintings that were to receive the most attention and acclaim, but rather the tapestries made by Frida Hansen's workshop.

Frida Hansen is considered one of Norway's leading art nouveau artists. She started her working career after her husband's bankruptcy, took up weaving at the end of the 1880s, and established her own workshop in 1897. Two years later her workshop was reorganized and given the name The Norwegian Tapestry Weaving Company [Det norske Billedvæveri]. She was then the leader of a company with more than twenty employees. ${ }^{54}$ The Norwegian Tapestry Weaving Company took on commissions, invited artists to submit cartoons for weaving, but also made an extensive collection of tapestries after Frida Hansen's own designs. Gerhard Munthe made and sold cartoons based on many of his decorative works, and Frida Hansen's firm bought the cartoons from him. ${ }^{55}$ The weaver Ulrike Greve - Frida Hansen's contemporary, who also made several tapestries based on Munthe's cartoons - considered the making of these motifs the greatest task of Norwegian tapestry weaving. She confessed that it must make every passionate weaver green with envy. ${ }^{56}$

Concerning the motifs, Hansen's tapestries featuring Sigurd and Baldwin and The Entry into Miklagard adhere strictly to Munthe's tempera paintings, but their colours are strikingly different. The sizes of the tapestries are also much more monumental: They each measure fifteen square meters. Did Munthe specify certain colours or were they chosen by Frida Hansen herself? Unfortunately, the cartoons' whereabouts is not known, and I have not been able to trace any correspondence

54 Frida Hansen, Hanne Beate Ueland, Janne Kathrine Leithe, and Arlyne Moi, Frida Hansen: art noveau i full blomst (Stavanger: Stavanger kunstmuseum, 2015), 16. See also Anikken Thue, Frida Hansen: en europeer i norsk tekstilkunst omkring 1900 (Stavanger: Universitetsforlaget, 1986), 52-6. 55 Greve, "Gerhard Munthe og den tekstile kunst," 97,100. I also thank Anniken Thue for information about how Frida Hansen and The Norwegian Tapestry Weaving Company obtained the cartoons for The National Tapestries.

56 Greve, “Gerhard Munthe og den tekstile kunst," 100. 
between the two. Given Munthe's interest in traditional tapestry weaving, one would expect him to have been diligent about the execution of tapestries based on his own works. Surprisingly, however, he did not seem much involved after he sold his cartoons. Ulrike Greve states that Munthe did not make himself available to the weavers, leaving them very much to their own devices. ${ }^{57}$

If Frida Hansen's experience was similar to Greve's, the colours might well have been Hansen's own choice. Compared to the colours of the paintings, the colours of the tapestries are more subdued. ${ }^{58}$ The backgrounds of the main motifs are dominated by beige and brown nuances. The lower parts of the tapestries - the medallions and the frieze - are also characterized by earth colours, mainly different shades of brown. In the two main motifs, bright colour accents are added: most conspicuously the red cloak of Sigurd, and the ochre caparisons.

While Greve concluded generously that Frida Hansen solved the task of weaving the two tapestries with honour, Gerhard Munthe was not too happy with the result. In a letter to his friend, art historian Andreas Aubert, he recognizes that the tapestries are well executed, but does not see them as artistically successful, because "the colours, with the exception of two, did not adhere to the idea of the compositions or to my original." ${ }^{59}$ How then did the public regard the tapestries?

\section{Reception and Debate}

Though Munthe was critical, critics were delighted when the two tapestries of Sigurd the Crusader were first exhibited in Kristiania, in the spring of 1900. The exhibition was arranged by The Norwegian Tapestry Weaving Company and presented the collection of tapestries woven by Frida Hansen's workshop that was to be shown at the Exposition Universelle in Paris later the same year. ${ }^{60}$ The exhibition was very positively received, especially the two tapestries of King Sigurd the Crusader. The art historian Rolf Thommessen, writing for the newspaper Verdens Gang, compared the tapestries with Grieg's music:

Norsemen, ever bound for new horizons be! The two tapestries, where Gerhard Munthe makes Sigurd the Crusader ride out of Jorsal and into Myklagaard, are as splendid as Grieg's music is.

57 Greve, “Gerhard Munthe og den tekstile kunst," 100.

58 According to art historian Ingeborg Lønning, at the Royal Palace the colours have faded somewhat (e-mail: 26.10.2017). When the tapestries were shown in Queen Sonja's Art Stable during summer 2018, it was possible to get a glimpse of the reverse side of the tapestries. It showed that the background of the frieze depicting Sigurd's fleet was originally blue.

59 Letter from Gerhard Munthe to Andreas Aubert, January 1, 1903 (The National Library of Norway). Cited from Kokkin, Gerhard Munthe. En norsk designpioner, 82. "aldenstund alle Farver paa to nær er udenfor Kompositionenes Tankegang og min Original."

60 Thue, Frida Hansen: en europeer i norsk tekstilkunst omkring 1900, 67, 72. 
A sound of festivity fills the air and makes them shine like a clear day in the large room, with an undertone of Norwegian colour, similar to the weft of folksong in our music. ${ }^{61}$

In addition to the strong synaesthetic bent of Thommessen's critique, he clearly voices the theme "Norway in the world," which, as we have seen, was an important concern at the time. This theme applies both to Sigurd the Crusader and to the tapestries going to be shown at the Exposition Universelle in Paris. The Norwegian poet and author Vilhelm Krag, writing for the newpaper Morgenbladet, praises the tapestries' style and colours:

Munthe's tapestries have a vigorous celebratory character of their own. Their lines are large and sharp-edged, their colours simple and virile. His straight-backed posture and fair skin are somehow suggestive of nascent majesty. . . . It is like the proud, unadorned style of the saga, transformed into colours. ${ }^{62}$

While Thommessen considers the tapestries in musical terms, Krag compares their style to the literary style of the sagas. In both cases they are linked to other art forms considered to be outstanding expressions of national character. In Krag's critique, their linear, simple, and dignified style is also clearly associated with masculinity.

Frida Hansen and her workshop not only presented the tapestries of Sigurd the Crusader, but also contributed a collection of tapestries based on Hansen's own designs. Her two main works were "The Dance of Salomé” [Salomes dans] (Fig. 28.10) and "The Five Wise and the Five Foolish Virgins" [De fem kloge og de fem daarlige Jomfruer]. Her choice of motifs was based on those of old Norwegian tapestries, but stylistically her works were distinctly art nouveau. Several of the critics compared Munthe's and Hansen's works, and in these discussions, questions about which works represented a true national art were prominent. Interestingly, these questions were also connected with gender issues. Krag's critique in Morgenbladet continued: “In contrast, Mrs Frida Hansen's monumental 'The Dance of Salomé' seems effeminately oriental." ${ }^{63}$ Rolf Thommessen also

61 "Norrønafolket, det vil fare! En Pragt som Griegs Musik ejer de to Tæpper, hvor Gerhard Munthe lader Sigurd Jorsalfar ride ud av Jorsal og ind i Myklagaard. En Klang af Fest, der fylder Luften og lader dem lyse som en klar Dag i det store Rum, og i en Undertone af norsk Farve som Folkevisens Islæt i vor Musik.” Rolf Thommessen, “Det norske Billedvæveri,” Verdens Gang, March 12, 1900.

62 "Der er over Munthes Billedvæv en egen kraftfuld Festivitas. Linierne er store og meislede, Farverne enkle og mandige. Der er ligesom en majestætisk Optakt over Sigurd Jorsalfars lyse, ranke Skikkelse. . . . Det er ligesom Sagaens knappe, stolte Stil omsat i Farver.” Morgenbladet, March 13, 1900, signed VK. Art historian Jan Kokkin has identified VK as Vilhelm Krag. Kokkin, Gerhard Munthe. En norsk designpioner, 82.

63 "I Modsætning dertil virker Fru Frida Hansens mægtige Salomes Dans blødaktig orientalsk." Vilhelm Krag, Morgenbladet, March 13, 1900. 


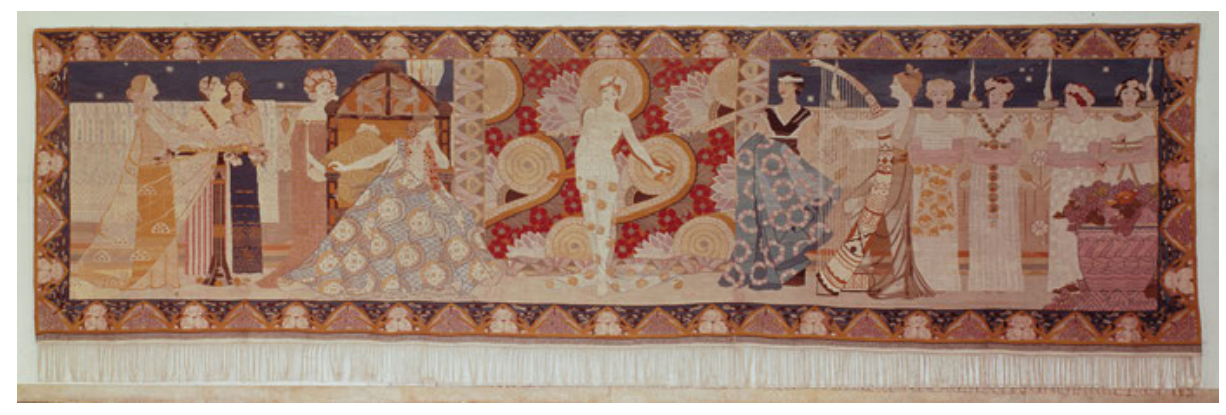

Fig. 28.10: Frida Hansen, The Dance of Salomé, 1900. 193 x $682 \mathrm{~cm}$. Museum für Gestaltung, Zürich.

contrasted the masculine style of Munthe's art with the feminine style of Frida Hansen's:

If Munthe's art is manly, because it is never afraid of underlining contrast, and because it is satisfied only with what is most distinct in form as well as in colour, it is not difficult to see that Mrs Frida Hansen's tapestries are made by a woman. The colours are much more subdued and more seductive, the forms softer and her art is on the whole more softspoken. ${ }^{64}$

Art historian Anniken Thue compares the receptions of Frida Hansen's and Gerhard Munthe's works when they were shown in Kristiania and in Paris. She concludes that both were praised for their works. However, it was generally Frida Hansen's ornamental works - for example tapestries with floral motifs - that found favour with the critics. Tapestries like "The Dance of Salomé” were habitually compared with Munthe's works and were criticized for a lack of national character. ${ }^{65}$

After the exhibition in Kristiania, Frida Hansen's and Munthe's tapestries were exhibited in the Norwegian pavilion at the Exposition Universelle which opened in Paris in April 1900. Norway contributed a large number of tapestries which in general were favourably received by the international critics. ${ }^{66}$ Ferdinand Leborgne,

64 "Er Munthes kunst mandig, fordi den aldrig frygter for at understrege Modsætninger, og fordi den i Form som i Farve kun nøjer sig med det mest utprægede, saa er det ikke vanskelig at se, at Fru Frida Hansens Tepper er gjort af en Kvinde. Farverne er langt blødere og mere indsmigrende, Formerne mygere, og den hele kunst stilfærdigere." Rolf Thommessen, "Det norske Billedvæveri," Verdens Gang, March 12, 1900.

65 Thue, Frida Hansen: en europeer i norsk tekstilkunst omkring 1900, 74. Thue points out a paradox, because Hansen's motifs were also firmly rooted in the Norwegian tapestry tradition. The Five Wise and the Five Foolish Virgins was, for example, the theme of a Norwegian tapestry from about 1650 which was known at the time.

66 In addition to works by Gerhard Munthe and Frida Hansen's company The Norwegian Tapestry Weaving Company, tapestries made at Nordenfjeldske Kunstindustrimuseums Vævskole og Atelier for Kunstvævning were on show. K. V. Hammer, Norges Deltagelse i Verdensudstillingen Paris 1900: Beretning (Kristiania: Det Mallingske Bogtrykkeri A/S, 1904), 69. 
who wrote the official report of the jury, praised the Norwegian tapestry production as "a true revelation to the world." 67 He credits Munthe for having created a true national decorative style. ${ }^{68}$ The Norwegian Tapestry Weaving Company received a gold medal for their collection of tapestries, including the two tapestries of Sigurd, and both Frida Hansen and Gerhard Munthe received gold medals for their participation in the making of the tapestries. ${ }^{69}$

\section{The Making of The National Tapestries}

In March 1900, shortly before the Exposition Universelle opened in Paris, a group of twenty-seven prominent Norwegian citizens submitted a proposal to the Norwegian Parliament. They represented many different occupations and professions and included artists, academics, lawyers, politicians, churchmen, and several others. ${ }^{70}$ They were concerned that the tapestries might be bought and taken out of the country, and urged Parliament to grant the necessary sum to secure them for the Norwegian State. They argued that the tapestries represented the pinnacle of a new national art, and thus it would be appropriate if the Norwegian State bought them before the exhibition in Paris opened and presented them as a national treasure. ${ }^{71}$

67 "sand aabenbarelse for alverden." Hammer, Norges Deltagelse i Verdensudstillingen Paris 1900: Beretning, 172.

68 Hammer, Norges Deltagelse i Verdensudstillingen Paris 1900: Beretning, 173. Leborgne does not explicitly mention The National Tapestries, and he also praises Frida Hansen and Augusta Christensen. The international reception in general did not draw such a clear line between Munthe's and Hansen's works regarding national character. Thue, Frida Hansen: en europeer $i$ norsk tekstilkunst omkring 1900, 78.

69 Munthe's participation at the exhibition also included a selection of paintings, and he was dissatisfied because he did not in addition receive the Grand Prix for these works. On the controversy of the medals, see Thue, Frida Hansen: en europeer i norsk tekstilkunst omkring 1900, 80-2; and Kokkin, Gerhard Munthe. En norsk designpioner, 85.

70 The proposal was signed by art historian Andreas Aubert; the painters Eilif Peterssen and Erik Werenskiold; director of the Museum of Decorative Arts and Design Henrik Grosch; museum pioneer Hans Aall; polar explorer and national hero Frithjof Nansen; historian Ernst Sars; philologist and translator Alexander Seippel; chief librarian Axel Charlot Drolsum; psalmist Elias Blix; metereologist Henrik Mohn; folklorist Moltke Moe; architect Adolf Schirmer; lawyer Bernhard Getz; E. Schønberg; mathematician Elling Holst; former prime minister Francis Hagerup; historian Alexander Bugge; art historian Lorentz Dietrichson; writer Arne Garborg; bishop Anton Christian Bang; lawyer Nikolaus Gjelsvik; linguist Hans Ross; priest Christopher Bruun; singer and composer Thorvald Lammers; and the mayor of Kristiania, Hagbard Emanuel Berner.

71 Stortinget, "Indst. S. XXVI. Indstilling fra budgetkomiteen angaaende bevilgning til videnskabelige, litterære og kunstneriske formaal (St. Prp. Nr. 1, hovedpost IV, kap. 3, St. Prp. Nr. 38 samt dok. Nr. 9, 10, 12 og 38)," accessed November 3, 2017, https://www.stortinget.no/no/Saker-og-publikasjoner /Stortingsforhandlinger/Lesevisning/?p=1899-00\&paid=6\&wid=a\&psid=DIVL2217\&pgid=a_1612. 
Furthermore, they argued that "as national tapestries" the works would "speak loud and clear . . . about the old roots and sovereignty of the Norwegian Kingdom."72 The proposal also suggested that the tapestries be given a ceremonial role. It was pointed out that the format of the tapestries had been chosen to fit the Cathedral at Trondheim (today's Nidaros Cathedral), and that it would be particularly appropriate to use them at coronation ceremonies: "They will, in particular during coronation ceremonies in the Dome of Olaf, both for the heirs of the Norwegian throne, as well as for the Norwegian people, respectfully bear witness to the prestige of our ancient kingdom." ${ }^{\text {,3 }}$ It was suggested that the tapestries should be kept at one of Norway's three museums of decorative art and design. However, because these museums did not possess the means to buy the tapestries, the proposers urged Parliament to grant the necessary sum of 10,800 Norwegian Kroner in order to secure them "as national tapestries for the Norwegian State." ${ }^{74}$ Judging from the material I have studied so far, this proposal seems to launch the term National Tapestries. At times, the tapestries were also referred to as The Jorsal Tapestries [Jorsal-teppærne]. Yet, giving them the name The National Tapestries was an important statement and argument. Was the Parliament convinced by it?

The committee discussing the proposal concluded that although several of its members were sympathetic to the cause, the budget was already stretched. Therefore, with the exception of one member (Carl Berner), they recommended that the grant not be made. The committee's recommendation was presented to Parliament, and the matter was discussed and put to a vote on May 22, 1900. All but fifteen members voted against buying the tapestries.

The very same day, the newspaper Verdens Gang published an article by art historian Andreas Aubert - one of the proposers. In his article, several of the arguments of the original proposal were repeated and elaborated. He started by stating that the art of tapestry weaving had deep roots in Norway, and drew a line from the Middle Ages up to his own times, stating that this old tradition was still alive in remote areas in Norway. He pointed out that at the very time peasants were giving

72 "Som Norges rigstepper vil de overfor verden tale klart og lydt . . . om det norske kongedømmets gamle rodfæstede suverænitet . . . ." Stortinget, “Indst. S. XXVI. Indstilling fra budgetkomiteen angaaende bevilgning til videnskabelige, litterære og kunstneriske formaal (St. prp. nr. 1, hovedpost IV, kap. 3, St. prp. nr. 38 samt dok. nr. 9, 10, 12 og 38).”

73 "særlig under kroningshøitiderne i Olafs dôm vil de, for arvtagerne af Norges kongetrone, som for det norske folk, vidne pietetsfuldt om det ældgamle kongedømmes heder.” Stortinget, "Indst. S. XXVI. Indstilling fra budgetkomiteen angaaende bevilgning til videnskabelige, litterære og kunstneriske formaal (St. prp. nr. 1, hovedpost IV, kap. 3, St. prp. nr. 38 samt dok. nr. 9, 10, 12 og 38)." I have not yet succeeded in finding out more about the decision to choose a format that would fit the interior of the Nidaros Cathedral. On St Olav and Nidaros Cathedral, see also Chapter 14 (Øystein Ekroll), vol. 1, 270-98.

74 “som rigstepper for den norske stat.” Stortinget, “Indst. S. XXVI. Indstilling fra budgetkomiteen angaaende bevilgning til videnskabelige, litterære og kunstneriske formaal (St. prp. nr. 1, hovedpost IV, kap. 3, St. prp. nr. 38 samt dok. nr. 9, 10, 12 og 38).” 
it up, men and women in the towns were reviving the old art of tapestry weaving. ${ }^{75}$ Although Aubert regarded buying the tapestries to be a national responsibility, he also appealed to private donors, in case Parliament declined.

What happened after Parliament refused to buy the tapestries? About a year later, in March 1901, the tapestries reappeared in a short notice in the newspaper Aftenposten concerning their being mounted in the main staircase of the Royal Palace. The hanging is only a trial: Electrical wiring is being installed in the Palace and the works involved could damage the tapestries. The notice states that the tapestries had indeed been bought on the initiative of and by donations from a number of private citizens, and given to the Royal Palace. ${ }^{76}$ Their action ensured that the tapestries remained in Norway. Moreover, by donating them to the Royal Palace, and not to one of the Norwegian museums, they also managed to strengthen their symbolic significance. Their being hung in the main staircase - where every visitor to the Palace would encounter them - suggested, very directly, an association between King Sigurd and the contemporary Kingdom of Norway (Fig. 28.3). Paradoxically perhaps, when the tapestries were first mounted, the king was Oscar II, King of Sweden and Norway.

Although Parliament had refused to buy the tapestries, they appeared once again on its agenda. In the state budget for 1902-1903, a proposal was made to grant 1,000 Norwegian Kroner to secure The National Tapestries - which by now had been placed permanently in the Royal Palace - and to paint the walls a more suitable colour. Following expert advice, the government proposed to secure the works by mounting protective textiles on their reverse sides, and to provide curtains which could cover them when the Palace was not in use. ${ }^{77}$

When the matter was debated in Parliament November 14, 1902, the proposal had already been reduced to 300 Norwegian Kroner and the representatives were to decide only for or against the security measures. One member considered these measures to be "a pure waste," but after the Minister of Finance, Elias Sunde, had explained the matter more carefully, the proposal was adopted unanimously. ${ }^{78}$ This

75 Albert Aubert, "Jorsalfar-Tæpperne. Luksus eller Statsøkonomi," [The Jorsalfar Tapestries. Luxury or Economy of State], Verdens Gang, May 22, 1900.

76 "I Slottets Hovedopgang," [In the Main Entrance to the Royal Palace] Aftenposten, March 20, 1901. So far, I have not been able to ascertain who were the generous donators. Judging from the notice in Aftenposten, it seems likely that the money was raised mainly by or among the men who had signed the original proposal.

77 St. prp. nr. 1. Hovedpost 1. (1902-1903) Det kongelige hus og de til hans Majestæt Kongens disposition stillede Statseiendomme [The Royal Palace and the other Properties of State at his Majesty the King's Disposition], p. 4, accessed November 3, 2017. https://www.stortinget.no/no/Saker-og-publikasjoner/ Stortingsforhandlinger/Lesevisning/?p=1902-03\&paid=1\&wid=a\&psid=DIVL1951\&pgid=a_1142.

78 "rent sløseri." The Minister of Finance mentions that the tapestries had been bought for NOK 8,000 , that is, NOK 3,300 less than their original price. Stortinget, "Møde den 14de november kl.10 form," accessed November 3, 2017, https://www.stortinget.no/no/Saker-og-publikasjoner/ Stortingsforhandlinger/Lesevisning/?p=1902-03\&paid=7\&wid=a\&psid=DIVL640\&pgid=a_0349. 
decision demonstrates that although the tapestries were bought by private means, Parliament felt some responsibility for securing the works once they had been donated to the Royal Palace.

Aubert's and the other proposers' vision of using the tapestries at coronation ceremonies in the Nidaros Cathedral was never realized. The National Tapestries continued to embellish the main staircase at the Royal Palace until the 1990s. At that time, they were taken down in connection with the extensive restauration works at the Palace, which took place from about 1993 to 2000. In 2015 the tapestries were on loan for the exhibition The Magic North in Helsinki, and in the summer of 2018 they were shown at the exhibition Tradition and Inspiration in Queen Sonja's Art Stable in Oslo. Except for these two exhibitions, the tapestries have been stored in the magazines of the Royal Palace. The decision to store them rather than remount them in their former place might well be due to concerns about their conservation. However, it is difficult not to reflect on changes of mentality and political climate that have taken place during the last century, concerning nationalism in general and the Crusades in particular. Although the tapestries maintain their great decorative effect, their heroic portrayal of King Sigurd on his crusade to the Holy Land might today seem somewhat problematic. 
